\title{
The Study on Living Standards and Satisfaction in Migrant Dorms
}

\author{
Kavitha Muthukumaran, Vani Haridasan and D.Varathakrishnan \\ SSN School of Management, Kalavakkam - 603110,Tamil Nadu, India; mkavitha@ssn.edu.in, \\ vanih@ssn.edu.in, 2k16varathakrishnan.d@somca.ssn.edu.in
}

\begin{abstract}
Objectives: To understand the living standards of the migrant dorms and to find out the satisfaction level of migrants with respect to the facilities provided in the dorms. Methods / Statistical Analysis: The design used for this study is Descriptive research design as it is used to describe the characteristics of the migrants included in this study. The population that was taken for study is the migrant workers in Chennai, India. Only the blue collar men are taken for study. The sample taken for the study is 50 respondents. The technique used for selecting the sample is convenient sampling. The study has used primary data. For collecting primary data structured questionnaire was framed and this questionnaire was pilot tested and necessary corrections have been implemented. Statistical tools namely correlation, cross tabulation and percentage analysis are applied in relevant places to prove to obtain the objective. Findings: Accommodation, Food, Television and washroom facility are the most commonly provided facilities in the dorms. Cleanliness is not up to the standard and it is of the least requirement in most of the dorms. Food is provided in all the dorms, but the quality and the service is not up to the mark. Providing food on time doesn't happen in the dorms. First-Aid/Medicine is not present in many dorms. The FirstAid/Medicine is a least priority for the migrants also. The statistical results of the study in cross tabulation shows that the lesser the expense is, higher the satisfaction. The correlation between age and satisfaction level of the migrants, established that there exists a low positive co- relation (0.316). When the correlation between age and recommending dorms by the migrants to others is studied, it is found that there exists a low positive co-relation (0.238) between both. There is a good correlation between Satisfaction and Recommendation of dorms to others. This means higher the satisfaction, higher the recommendation of dorms to others. Applications / Improvements: From the above study, it is evident that the experience is the factor which is missed out in all the dorms. The standards are lower all over the city, so the migrants get satisfied with what they get. But, if we provide them better benefits at low cost, the standard of living of the migrants to stay in the dorms can be brought up.
\end{abstract}

Keywords: Basic Requirements, Facilities, Living Standards, Migrant, Dorms, Satisfaction Level

\section{Introduction}

In India, Chennai city is the 4th largest city. Out of 33 districts in the state of Tamil Nadu, Chennai is one among them. It is smallest of the entire district but Chennai has the highest human density. Chennai city is the fourth largest metropolis in India. The reason behind it is massive urbanization. It is the capital city of the Tamil Nadu state and also having the major commercial, educational and industrial centers of south India. Many people get migrated from their hometown and get settled in Chennai for their livelihood. Hotel industries, hostel, paying guest are becoming of massive demand because of these migrants getting settled in Chennai.

Many employees from other states and districts have started to migrate from their places to Chennai for their livelihood. This made many Hotel industries, hostels, paying guest and rental apartments to earn based on these people but without providing proper facilities. Hotel industry has grown rapidly. Hotels have transformed majorly to hospitality industry to attract the travelers.

Dormitory refers to a number of private or semiprivate rooms for residents, usually along with common bathroom facilities and recreation areas. 
Considerable proportion of migrated population particularly in large and metropolitan cities lives in marginal settlements, slums and squatter areas with limited infrastructure services threatening health, environmental degradation of urban areas, traffic and other problems of urban areas. The study describes the factors contributing towards rural to urban migration. In rural areas, less employment opportunities, low wages, drought, lack of basic amenities, landlessness, social factors act as push factors and more employment opportunities, higher income, better wages, better facilities activities as pull factors towards the rural to urban migration. The concept of "Home Sharing" refers to this kind of settlement among migrants and this term originated here. In simple terms, "home sharing" is an arrangement by which two or more unrelated people share a dwelling within which each retains a private space.

Tamil Nadu is home for a million Migrant Workers. Out of it, nearly 1.9 Lakhs live in Chennai. The study is concentrated on Chennai where the migrants are of huge numbers because of the highest demand in construction, painting, and security requirements.

The Hostel industry under which the dorms come has been in highest growth because of the demand in the recent years. The facilities provided in the dorms seem to be similar. Various unwanted facilities are provided, whereas the required factors are missed out.

As far as the project is concerned, the company wants to understand the living standards in dorms and the satisfaction in them.

\section{Need for Study}

The Living condition seems to be not up to the mark. Also, the values provided in the dorms are basically similar all over the city. Dorms think of providing tangible benefits like Wifi, TV, etc which has been provided by other competitors also, making it reach a saturation point. The satisfaction is not only dependent on the physical components provided by dorms. The dorms lack the experience which is absent in all the dorms. The study helps to identify the missing parts.

\section{Objective of the Study}

1. To understand the living standards in Migrant Dorms.

2. To find out the satisfaction level of Migrants with respect to the facilities provided in the dorms.

\section{Scope of the Study}

The scope of study is restricted to Migrant Blue collar Workers in Chennai with a monthly salary of less than Rs.20,000. Migrants from different demographics are contacted and interviewed in their preferred language. For the study, only men are considered. The responses are then noted down in the sheet.

\section{Literature Survey}

In $^{1}$ investigated that $45.9 \%$ of all enrolled students the scores for depression ranged from mild to moderate (female: $54 \%$, male: $41 \%$ ). They had more time to study and do exercises. Factor analysis was conducted and the depressive group had a more manifest depressed mood and 50 percentage higher ZSDS items score than the normal group: core depressive factor and anxiety factor.

$\mathrm{In}^{2}$ suggested for more attention and support towards the effect of floor height on the perception of room size and the feel of crowding. In this study, even though all the rooms were of the same size and had the same number of individuals living in them (were of equal density), residents of the highest and lowest floors had significant different ratings of perceived room size and crowding.

$\mathrm{In}^{3}$ studied about the Students' Satisfaction with Hostel Facilities in Federal University of Technology, Akure, Nigeria. The author focused on the facilities provided by the hostel and he satisfaction level of the students on those facilities. The facilities available in the hostels include electricity, water supply, waste disposal, toilets, bathrooms, laundry, kitchenette, ICT/reading room, fire fighting equipments, security and recreation areas among others. The results reveal that most of the students are dissatisfied with the facilities provided in the hostel because of not many students available in the hostel and the other reason might be location of the hostel.

$\operatorname{In}^{4-6}$ studied about the relationship between customer loyalty and customer satisfaction. This study focused on the relationship between customer loyalty and satisfaction and to understand the benefits of loyalty provided to customer, also to understand whether customers are satisfied with those benefits and become a loyal customer and to understand their current performance. The results indicate the relationship between satisfaction and loyalty is non - linear. The study was conducted based on the data collected from hotel's database to draw samples for both focus group and mail survey. The total completed 
survey was 564 from hotel guests, and the relationship was found to be non - linear. This shows that even the customers are satisfied with any of the facilities; loyalty comes only when they are being valued.

\section{Research Gap}

Only tangible things are taken for measurements of satisfaction, be it Design of Room, Facilities provided, etc., while the intangible things like experience is not taken during study.

\section{Methodology}

\subsection{Research Design}

The design used for this study is Descriptive research design as it is used to describe the characteristics of the migrants included in this study.

\subsection{Population and Sample}

The population that was taken for study is the migrant workers in Chennai in India. Only the blue collar men are taken for study. The sample taken for the study is 50 respondents. The technique used for selecting the sample is convenient sampling.

\subsection{Source of Data}

The study has used primary data. For collecting primary data structured questionnaire was framed and this questionnaire was pilot tested and necessary corrections have been implemented.

\subsection{Statistical Tools}

Statistical tools namely correlation, cross tabulation and percentage analysis are applied in relevant places to prove to obtain the objective.

\section{Results and Findings}

\subsection{Analysis}

Data is collected from 50 Migrants who use Dormitories in Chennai. This only includes people who has monthly salary lesser than Rs.20,000 per month.

Analysis Flow

- Percentage analysis is applied to understand the demographic and social factors of respondents.

- Cross tabulations for Expense to Income Ratio vs Satisfaction of the dorms were made. Also, Cross tabulation between Age $v s$. Wifi speed a concern, is also made.

- Correlation

- Between age and satisfaction of the migrants.

- Between age and recommendation of the migrants.

- Between satisfaction and recommendation of the migrants.

The study of descriptive analysis showed that $36 \%$ of the migrants are above 58 and $30 \%$ of the migrants are under the category of 35-45 years of age. Among the migrants considered for the study, the analysis shows that the income range of the migrants fall under the category of

Table 1: Descriptive Analysis of Demographic factors and Socio economic factors of the Migrants

\begin{tabular}{|c|c|c|c|c|}
\hline S.NO & Sample & Sub Sample & \# RESPONDENTS & $\%$ \\
\hline \multirow{5}{*}{1.} & \multirow{5}{*}{ Age Group } & $<25$ & 2 & $4.00 \%$ \\
\hline & & $>58$ & 18 & $36.00 \%$ \\
\hline & & $25-35$ & 1 & $2.00 \%$ \\
\hline & & $35-45$ & 15 & $30.00 \%$ \\
\hline & & $45-58$ & 14 & $28.00 \%$ \\
\hline \multirow{3}{*}{2.} & \multirow{3}{*}{ Income per month } & $<10,000$ & 11 & $22.00 \%$ \\
\hline & & $10,000-15,000$ & 24 & $48.00 \%$ \\
\hline & & $15,000-20,000$ & 15 & $30.00 \%$ \\
\hline \multirow{3}{*}{3.} & \multirow{3}{*}{ Expense to the Salary } & $<30 \%$ & 28 & $56.00 \%$ \\
\hline & & $30-40 \%$ & 10 & $20.00 \%$ \\
\hline & & $40-50 \%$ & 12 & $24.00 \%$ \\
\hline
\end{tabular}


Table 2: Analysis to find out the satisfaction level of migrants in Dorms

\begin{tabular}{|c|c|c|c|c|}
\hline S.NO & Sample & Sub Sample & \# RESPONDENTS & $\%$ \\
\hline \multirow{3}{*}{1.} & \multirow{3}{*}{ Food provided on time } & All the Time & 10 & $20.00 \%$ \\
\hline & & Hardly on Time & 10 & $20.00 \%$ \\
\hline & & Most of the Time & 30 & $60.00 \%$ \\
\hline \multirow{3}{*}{2.} & \multirow{3}{*}{ Bored with Existing Menu } & No & 7 & $14.00 \%$ \\
\hline & & Sometime & 25 & $50.00 \%$ \\
\hline & & Yes & 18 & $36.00 \%$ \\
\hline \multirow{2}{*}{3.} & \multirow{2}{*}{ Geyser in Washrooms } & No & 7 & $14.00 \%$ \\
\hline & & Yes & 43 & $86.00 \%$ \\
\hline \multirow{5}{*}{4.} & \multirow{5}{*}{ Satisfaction on Bed Comfort } & Highly Dissatisfied & 6 & $12.00 \%$ \\
\hline & & Dissatisfied & 8 & $16.00 \%$ \\
\hline & & Neutral & 4 & $8.00 \%$ \\
\hline & & Satisfied & 28 & $56.00 \%$ \\
\hline & & Highly Satisfied & 4 & $8.00 \%$ \\
\hline \multirow{3}{*}{5.} & \multirow{3}{*}{ Satisfaction on Air circulation } & Dissatisfied & 30 & $60.00 \%$ \\
\hline & & Neutral & 10 & $20.00 \%$ \\
\hline & & Satisfied & 10 & $20.00 \%$ \\
\hline \multirow{4}{*}{6.} & \multirow{4}{*}{ Satisfaction on Sanitation } & Dissatisfied & 4 & $8.00 \%$ \\
\hline & & Neutral & 24 & $48.00 \%$ \\
\hline & & Satisfied & 21 & $42.00 \%$ \\
\hline & & Highly Satisfied & 1 & $2.00 \%$ \\
\hline \multirow{4}{*}{7.} & \multirow{4}{*}{ Grievance Redressal } & Highly Dissatisfied & 7 & $14 \%$ \\
\hline & & Dissatisfied & 9 & $18 \%$ \\
\hline & & Neutral & 30 & $60 \%$ \\
\hline & & Satisfied & 4 & $8 \%$ \\
\hline \multirow{4}{*}{8.} & \multirow{4}{*}{ Satisfaction on Food Service } & Highly Dissatisfied & 10 & $20.00 \%$ \\
\hline & & Dissatisfied & 19 & $38.00 \%$ \\
\hline & & Neutral & 9 & $18.00 \%$ \\
\hline & & Satisfied & 12 & $24.00 \%$ \\
\hline \multirow{3}{*}{9.} & \multirow{3}{*}{ Satisfaction on Privacy Provided } & Dissatisfied & 30 & $60.00 \%$ \\
\hline & & Neutral & 10 & $20.00 \%$ \\
\hline & & Satisfied & 10 & $20.00 \%$ \\
\hline \multirow{5}{*}{10.} & \multirow{5}{*}{ Satisfaction of Dorm } & Dissatisfied & 3 & $6.00 \%$ \\
\hline & & Highly Dissatisfied & 2 & $4.00 \%$ \\
\hline & & Neutral & 9 & $18.00 \%$ \\
\hline & & Satisfied & 29 & $58.00 \%$ \\
\hline & & Highly Satisfied & 7 & $14.00 \%$ \\
\hline
\end{tabular}

$10,000-15,000$ per month is the highest with $48 \%$ of the total. The results of the frequency analysis show that the migrants save a lot. $56 \%$ of the migrants mentioned that their expense is only $30 \%$ of their income ${ }^{7}$.
The results of frequency Table 1 showed that only $20 \%$ of the time, the food is provided at the right time to the migrants. Also the frequency results showed that $86 \%$ of the migrants are bored with the existing menu. 


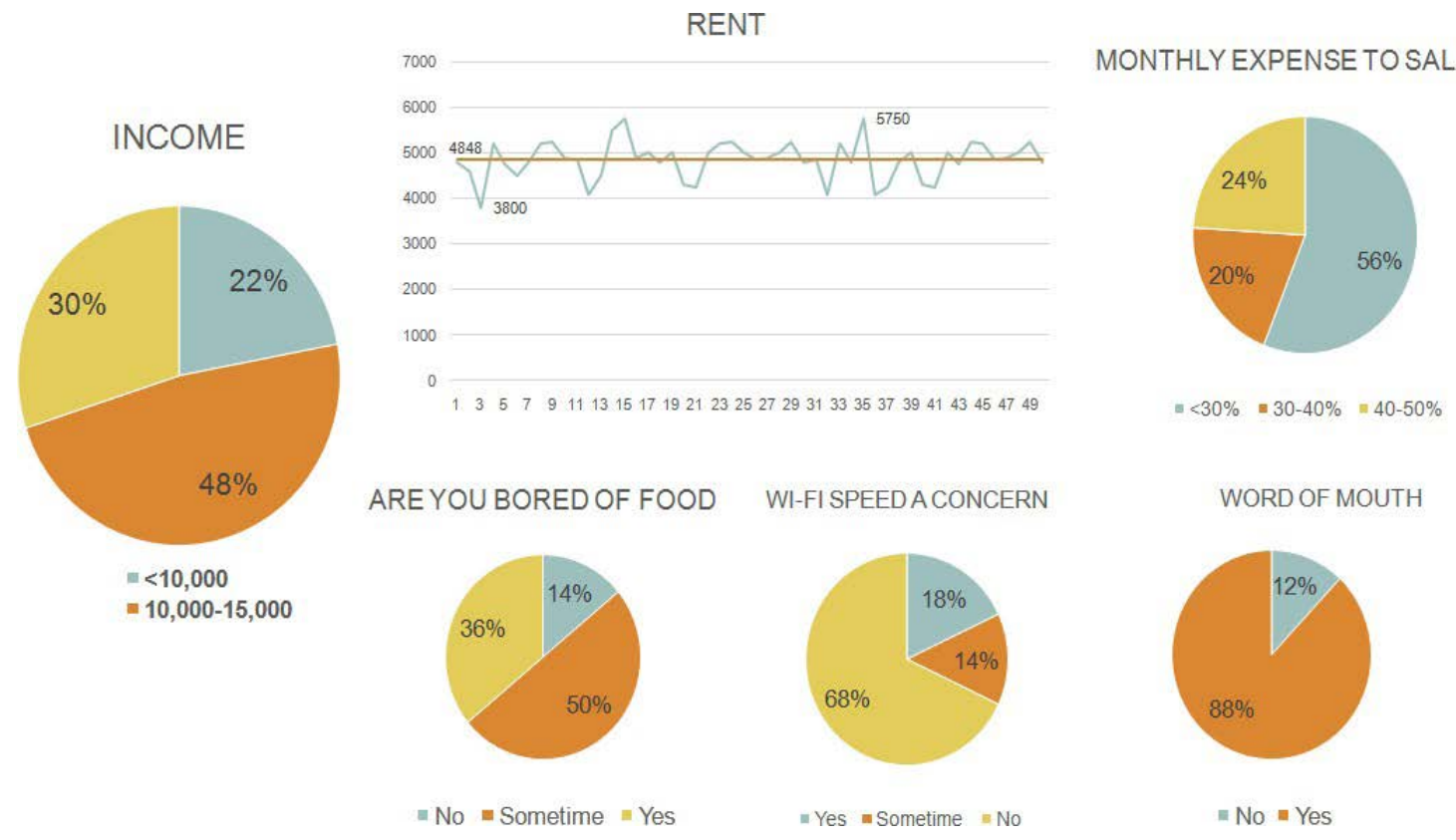

Figure 1. Analysis to find out the satisfaction level of migrants in Dorms

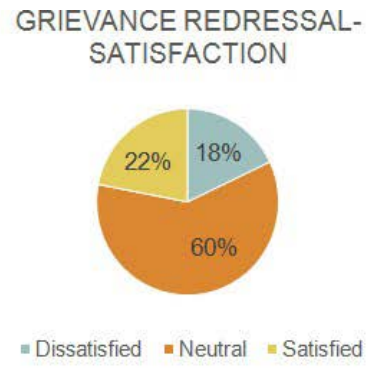

VALUE FOR MONEY

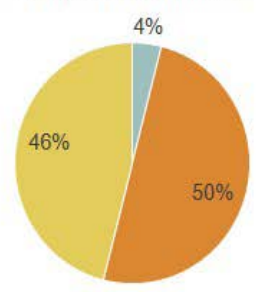

" Highly Satisfied $=$ Neutral $=$ Satisfied
FOOD SERVICE

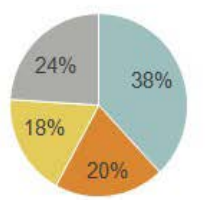

$=$ Dissatisfied

Neutral

= Highly Dissatisfied

- Satisfied

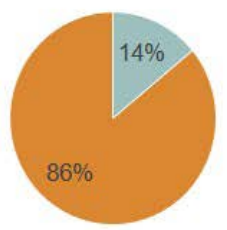

meutral $=$ Satisfied

PRESENCE OF COMMUNITY

PRIVACY

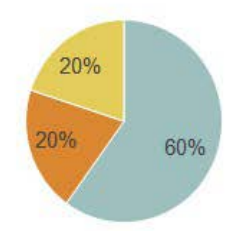

Dissatisfied $=$ Neutral $m$ Satisfied

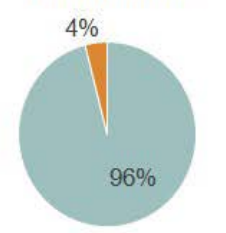

No $=$ Yes

Figure 2. Analysis to measure the satisfaction level of migrants in Dorms - Characteristics.

The analysis showed that $86 \%$ of the migrants said that their washrooms are fitted with geyser facility. From the total migrants surveyed, $60 \%$ of migrants in the dorms said that they are dissatisfied with the air circulation present in the room. The result also showed that nearly $42 \%$ of the migrants from the total migrants are satisfied with sanitation provided and $2 \%$ are highly satisfied.
Further the analysis showed that $58 \%$ of the migrants don't like the food service done in the dorms. $60 \%$ of the migrants are dissatisfied with the privacy in the dorm. $40 \%$ of the migrants feel that the current dorm has value for the money paid ${ }^{8-10}$.

The results of frequency analysis showed that $96 \%$ of the migrants said there is no community present for con- 
veying issues to the owner. $68 \%$ of the migrants said that wifi speed is not at all a concern. This might be because of the presence of personal low cost data plans.

Further to the above it is found in the study that nearly $88 \%$ of the migrants came to know about the dorms are shown in Figure 1 and 2 through word of mouth. Nearly $38 \%$ of migrants (19 respondents) are satisfied with the dorm when their expense to income ratio is less than 30\%. 56\% Respondents said that they are Satisfied with the bed quality present in the room.

From the study the following observations were made that are related to frequency analysis:

- Accommodation, Food, Television and washroom facility are the most commonly provided facilities.

- Cleanliness is not up to the standard in the dorms and also the least requirement, as they are used to conditions without cleanliness.

- Food is provided in all the dorms, but the quality and the service is not up to the mark.
- Most of the time the dorms are not providing food on time.

- First-Aid/Medicine is not present in many dorms. The First-Aid/Medicine is a least priority for the migrants also.

\section{Cross Tabulation}

Results of the cross tabulation shows that the lesser the expense is, higher the satisfaction. Nearly $38 \%$ of respondents (19 respondents) are satisfied with the dorms when their expense to income ratio is less than $30 \%$.

\section{Inference}

Wi-Fi speed is not at all a concern to the migrants in the various dorms in Chennai. $68 \%$ of the migrants said that Wi-Fi speed is not at all a concern. Only $8 \%$ of the migrants under the age group of 35-45 said that Wi-Fi speed is a concern for them and $4 \%$ of the migrants under the age group of $45-58$ and $>58$ age groups each said that Wi-Fi speed is a concern for them.

Table 3: Expense to Income Ratio Vs Dorm Satisfaction

\begin{tabular}{|c|c|c|c|c|c|c|c|c|c|c|c|c|}
\hline \multirow{2}{*}{\multicolumn{2}{|c|}{$\begin{array}{l}\text { Expense to } \\
\text { Income Ratio Vs } \\
\text { Satisfaction of } \\
\text { Dorm }\end{array}$}} & \multicolumn{11}{|c|}{ Satisfaction of Dorm } \\
\hline & & \multirow{2}{*}{$\begin{array}{l}\text { Highly } \\
\text { Satisfied }\end{array}$} & \multirow{2}{*}{\begin{tabular}{|l|}
$\%$ \\
$10 \%$
\end{tabular}} & \multirow{2}{*}{\begin{tabular}{|l} 
Satisfied \\
14
\end{tabular}} & \multirow{2}{*}{$\begin{array}{l}\% \\
28 \%\end{array}$} & \multirow{2}{*}{$\begin{array}{l}\text { Normal } \\
7\end{array}$} & \multirow{2}{*}{$\begin{array}{l}\% \\
14 \%\end{array}$} & \multirow{2}{*}{$\begin{array}{l}\text { Dissatisfied } \\
2\end{array}$} & \multirow{2}{*}{$\begin{array}{l}\% \\
4 \%\end{array}$} & \multirow{2}{*}{$\begin{array}{l}\begin{array}{l}\text { Highly } \\
\text { Dissatisfied }\end{array} \\
0\end{array}$} & \multirow{2}{*}{$\begin{array}{l}\% \\
0 \%\end{array}$} & \multirow{2}{*}{$\begin{array}{l}\text { Tota } \\
28\end{array}$} \\
\hline 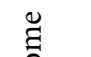 & $<30 \%$ & & & & & & & & & & & \\
\hline$\stackrel{\ominus}{\ominus}$ & $30-40 \%$ & 2 & $4 \%$ & 5 & $10 \%$ & 2 & $4 \%$ & 0 & $0 \%$ & 1 & $2 \%$ & 10 \\
\hline 希焉 & $40-50 \%$ & 0 & $0 \%$ & 10 & $20 \%$ & 0 & $0 \%$ & 1 & $2 \%$ & 1 & $2 \%$ & 12 \\
\hline \multicolumn{2}{|l|}{ Total } & \multicolumn{2}{|l|}{7} & \multicolumn{2}{|l|}{29} & \multicolumn{2}{|l|}{9} & \multicolumn{2}{|l|}{3} & \multicolumn{2}{|l|}{2} & 50 \\
\hline
\end{tabular}

Table 4: Age Vs WIFI Speed a Concern

\begin{tabular}{|c|c|c|c|c|c|c|c|c|}
\hline \multirow{2}{*}{\multicolumn{2}{|c|}{ Age Vs Wi-Fi Speed a Concern }} & \multicolumn{7}{|c|}{ Satisfaction of Dorm } \\
\hline & & No & $\%$ & Sometime & $\%$ & Yes & $\%$ & Total \\
\hline \multirow{5}{*}{$\underset{\pi}{\infty}$} & $<25$ & 1 & $2 \%$ & 0 & $0 \%$ & 1 & $2 \%$ & 2 \\
\hline & $25-35$ & 0 & $0 \%$ & 1 & $2 \%$ & 0 & $0 \%$ & 1 \\
\hline & $35-45$ & 9 & $18 \%$ & 2 & $4 \%$ & 4 & $8 \%$ & 15 \\
\hline & $45-58$ & 9 & $18 \%$ & 3 & $6 \%$ & 2 & $4 \%$ & 14 \\
\hline & $>58$ & 15 & $30 \%$ & 1 & $2 \%$ & 2 & $4 \%$ & 18 \\
\hline \multicolumn{2}{|l|}{ Total } & \multicolumn{2}{|l|}{34} & \multicolumn{2}{|l|}{7} & \multicolumn{2}{|l|}{9} & 50 \\
\hline
\end{tabular}


Table 5: Correlation between Age and Satisfaction of the migrants Correlations

\begin{tabular}{|ll|c|c|}
\hline & & Satisfaction & Age \\
\hline Satisfaction & Pearson Correlation & 1 & .316 \\
& Sig. (2-tailed) & & .000 \\
& $\mathrm{~N}$ & 50 & 50 \\
\hline Age & Pearson Correlation & .316 & 1 \\
& Sig. (2-tailed) & .000 & 50 \\
& $\mathrm{~N}$ & 50 & \\
& & & 50 \\
\hline
\end{tabular}

Table 6: Correlation between Age and Recommendation of the migrants

\section{Correlations}

\begin{tabular}{|ll|c|c|}
\hline & & Satisfaction & Age \\
\hline Age & Pearson Correlation & 1 & .238 \\
& Sig. (2-tailed) & & .000 \\
& $\mathrm{~N}$ & 50 & 50 \\
\hline Recommendation & Pearson Correlation & .238 & 1 \\
& Sig. (2-tailed) & .000 & 50 \\
& $\mathrm{~N}$ & 50 & \\
\end{tabular}

Table 7: Correlation between Satisfaction and Recommendation of the migrants Correlations

\begin{tabular}{|ll|c|c|}
\hline & & Satisfaction & Age \\
\hline Recommendation & Pearson Correlation & 1 & .668 \\
& Sig. (2-tailed) & & .001 \\
& N & 50 & 50 \\
\hline Satisfaction & Pearson Correlation & .668 & 1 \\
& Sig. (2-tailed) & .001 & 50 \\
& N & 50 & \\
\hline
\end{tabular}

\subsection{Correlation between Age and Satisfaction}

The correlation between age and satisfaction level of the migrants in the dorms, established that there exists a low positive co- relation $(0.316)$. The $\mathrm{p}$ value $(0.000)$ indicates that the relationship is significant.

\subsection{Correlation between Age and Recommendation}

When the correlation between age and recommending dorms to others is studied, it is found that there exists a low positive co-relation $(0.238)$ between both. The $\mathrm{p}$ value is 0.000 , less than 0.05 indicating that the relationship is significant.
When the correlation between satisfaction level of the migrants and recommending dorms to others is studied, it is found that there exists a moderate positive co-relation (0.668) between both. The $\mathrm{p}$ value is 0.000 , less than 0.05 indicating that the relationship is significant.

There is a good correlation between Satisfaction and Recommendation of the dorms to others. This means higher the satisfaction, Higher the Recommendation. (Since, 88\% People come to know about dorm through word of mouth)

\section{Summary of Findings}


Table 8: Descriptive Analysis of Demographic factors and Socio economic factors of the Migrants

\begin{tabular}{|c|c|c|}
\hline Frequency Analysis & Cross Tabulation & Correlation \\
\hline $\begin{array}{l}\text { Accommodation, Food, Television } \\
\text { and washroom facility are the most } \\
\text { commonly provided facilities. }\end{array}$ & $\begin{array}{l}\text { Results of the cross tabulation shows } \\
\text { that the lesser the expense is, higher the } \\
\text { satisfaction. Nearly } 38 \% \text { of respondents } \\
\text { ( } 19 \text { respondents) are satisfied with the } \\
\text { dorm when their expense to income ratio } \\
\text { is less than } 30 \% \text {. }\end{array}$ & $\begin{array}{l}\text { The correlation between age and } \\
\text { satisfaction level of the migrants, } \\
\text { established that there exists a low positive } \\
\text { co-relation }(0.316) \text {. }\end{array}$ \\
\hline \multirow[t]{2}{*}{$\begin{array}{l}\text { Cleanliness is not up to the standard and } \\
\text { also the least requirement in most of the } \\
\text { dorms. }\end{array}$} & $\begin{array}{l}\text { Wi-Fi speed is not at all a concern to the } \\
\text { migrants. } 68 \% \text { of the }\end{array}$ & $\begin{array}{l}\text { When the correlation between age and } \\
\text { recommending dorms by the migrants } \\
\text { to others is studied, it is found that there } \\
\text { exists a low positive co-relation }(0.238) \\
\text { between both. }\end{array}$ \\
\hline & $\begin{array}{l}\text { Migrants said that Wi-Fi speed is not at } \\
\text { all a concern. Only } 8 \% \text { of the migrants } \\
\text { under the age group of } 35-45 \text { said that } \\
\text { Wi-Fi speed is a concern for them and } 4 \% \\
\text { of the migrants under the age group of } \\
45-58 \text { and }>58 \text { age groups each said that } \\
\text { Wi-Fi speed is a concern for them. }\end{array}$ & \\
\hline $\begin{array}{l}\text { Food is provided in all the dorms, but the } \\
\text { quality and the service is not up to the } \\
\text { mark. }\end{array}$ & & $\begin{array}{l}\text { There is a good correlation between } \\
\text { Satisfaction and Recommendation of } \\
\text { dorms to others. This means higher the } \\
\text { satisfaction, higher the recommendation } \\
\text { of dorms to others. (Since, } 88 \% \text { People } \\
\text { come to know about dorm through word } \\
\text { of mouth) }\end{array}$ \\
\hline \multicolumn{3}{|l|}{$\begin{array}{l}\text { Providing food on time doesn't happen } \\
\text { on time. }\end{array}$} \\
\hline $\begin{array}{l}\text { First-Aid/Medicine is not present in } \\
\text { many dorms. }\end{array}$ & $\begin{array}{l}\text { The Aid/Medicine is a least priority for } \\
\text { the migrants also First. }\end{array}$ & \\
\hline
\end{tabular}

\section{Conclusion}

Findings resulted from the analysis of questionnaire responses coupled with field studies offer new understandings of present living standards and satisfaction of migrant knowledge workers in general. It is important not to draw ambitious conclusions from a cross-sectional survey, but some points are worth noting. The questions were constructed to give an objective response about living conditions in the dorms for migrants.

The study seeks to investigate living standards in the dorms for migrants and measure the satisfaction of the migrants who stay in those dorms. The Living standards in the dorms are very bad, being the standards are of least priority compared to a bed to sleep and food provided. The whole Hostel industry works based on demand and supply of the customers, and when migrants are ready to occupy dorms with low stan- dards of living, it is left aside and ignored. If the dorms are able to provide a grievance redressal committee will increase satisfaction. Wi-Fi speed is not a concern to majority of the migrants. So, it can be removed to reduce cost incurred. Experience improves satisfaction rather than providing materialistic benefits in the dorms. Food service plays an important role among all the other factors. Touch points should be identified and good experience should be provided.

Most of the dorms provide accommodation, food and washroom facility, there are few dorms which are constructed near public washrooms and hence they don't have their own washrooms. This project takes into account, the absence of customer experience which influences the satisfaction, in addition to the tangible benefits provided like Wi-Fi, TV, etc.

From the above study, it is evident that the experience is the factor which is missed out in all the dorms. The 
standards are lower all over the city, so the migrants get satisfied with what they get. But, if we provide them better benefits at low cost, the standard of living of the migrants to stay in the dorms can be brought up. The touch points like food service, having grievance redressal committee, Privacy for the people who stay, if improved can bring an experience to the dorm and materialistic benefits which are provided as induced standards like Wi-Fi can be cut down to reduce costs.

\section{References}

1. Psychological and Emotional Stress among the Students Living in Dormitory: A Comparison between Normal and Depressive Students. Date accessed: 31/05/2015. https://www.omicsonline.org/open-access/ psychological-and-emotional-stress-among-the-studentsliving-in-dormitory-acomparison-between-normal-anddepressive-students-2167-0277-1000201.php?aid=52702.

2. Kaya N, Erkip F. Satisfaction in a dormitory building: The effects of floor height on the perception of room size and crowding, Environment and Behavior. 2001; 33(1):35-53. https://doi.org/10.1177/00139160121972855.

3. Ajayi M, Nwosu A, Ajani Y. Students' satisfaction with hostel facilities in federal university of technology, Akure, Nigeria, European Scientific Journal. 2015; 11(34):402-15.

4. Bowen JT, Chen SL. The relationship between customer loyalty and customer satisfaction, International Journal of
Contemporary Hospitality Management. 2001; 213-17. https://doi.org/10.1108/09596110110395893.

5. Xiao Y, Maio S, Lu Y. Exploring the impacts of housing condition on migrants' mental health in nanxiang, shanghai: A structural equation modeling approach, International Journal of Environmental Research and Public Health. 2018; 15(2):225-75. https://doi.org/10.3390/ijerph15020225. PMid:29382174, PMCid:PMC5858294.

6. Salama AM, Wiedmann F, Ibrahim HG. Migrant knowledge workers' perceptions of housing conditions in gulf cities, Journal of International Migration and Integration. 2017; 19(1):15-33. https://doi.org/10.1007/s12134-0170527-z.

7. Jinseon $\mathrm{H}$, Sehwa Y, Perception of privacy and territoriality and residential satisfaction dormitory rooms, Journal of the Architectural Institute of Korea Planning and Design. 2002; 18(8):214-30.

8. Balbo M, Marconi G. International migration, diversity and urban governance in cities of the south, Habitat International. 2006; 30(3):706-15. https://doi. org/10.1016/j.habitatint.2005.04.004.

9. Ukoha OM, Beamish JO. Assessment of residents' satisfaction with public housing in Abuja, Nigeria, Habitat International. 1997; 21(4):445-60. https://doi.org/10.1016/ S0197-3975(97)00017-9.

10. Wiedmann F, Mirincheva V, Salama AM. Sustainable urban qualities in the emerging city of Doha, Journal of Urbanism. 2014; 7(1):62-84 https://doi.org/10.1080/17549175.2013.8 70088 . 